\title{
The Hierarchy of Human Rights and the Transcendental System of Right
}

\author{
Fernando Suárez Müller ${ }^{1}$ \\ Published online: 6 December 2018 \\ (C) The Author(s) 2018
}

\begin{abstract}
This paper analyses the relatively neglected topic of hierarchy in the philosophical foundation of human rights. It develops a transcendental-discursive approach. This approach develops the idea that all human rights could be derived from a small set of fundamental rights that are interconnected and that incorporate all ulterior possible specific rights. This set is then applied to an analysis of human rights as they have been formulated in the Universal Declaration of Human Rights. The claim is that this prior set of transcendental rights is discursively implied whenever we talk about human rights. Thinking about the hierarchy of rights pragmatically means thinking about prioritising their implementation. Some consequences for practical philosophy and politics concerning the role of states, enterprises and world citizenship are then discussed.
\end{abstract}

Keywords Human rights · Transcendental approach · Hierarchy of rights · System of right . Natural law $\cdot$ Right to personhood

\section{Introduction}

The problem of the hierarchy of rights is a central element in the traditional philosophy of right. Johann Gottlieb Fichte (1796) was one of the first who, following Immanuel Kant's moral theory, started a systematic study based on transcendental philosophy (Fichte 1971, 17-23, 92-110). Kant's own system of right appeared a year later (1797) ${ }^{1}$, and after some decades, Georg Wilhelm Friedrich Hegel combined a hierarchical system of right with a comprehensive social theory and social history. ${ }^{2}$ Since

\footnotetext{
${ }^{1}$ See especially Metaphysik der Sitten (A43-50).

${ }^{2}$ Hegel combines hierarchy with the development of different levels (Stufengängen) of right (Hegel 1986c, VII, 87).
}

Fernando Suárez Müller

fsm@uvh.nl

1 University of Humanistic Studies, Kromme Nieuwegracht 29, 3500 AT Utrecht, the Netherlands 
Abraham Maslow's work (Maslow 1954) on the psychological pyramid of needs, there has been increasing attention on the hierarchy of rights and norms, especially concerning the problem of international law (Wuerffel 1998; Koji 2001; Klein 2008). But, apart from the particular issue of the non-derogative aspect of human rights and the generational differences between several conventions, ${ }^{3}$ hierarchy is still not generally considered to be a central part of a systematic philosophical approach to human rights.

In his empirical approach, Henry Shue speaks of 'basic rights' (Shue 1996, 30), focusing his ideas on fundamental human needs (subsistence and security), but he does not develop a philosophically grounded theory of hierarchy (Farer 1992, 116). Donnelly $(1984,2002)$ devotes much time to the issue of the universalism and relativism of human rights, but the phenomenon of the hierarchy of rights receives no special attention. In his theory of justice, John Rawls avoids the notion of 'hierarchy', but he speaks of a 'lexical order' by which he means a 'ranking of rights' (Rawls 1971, 42-43). The term lexical order, however, is confusing and in fact inadequate to express the vertical dependencies within a System of Right. The order in such system is not lexical (or lexicographical) as, for example, in a dictionary but transcendental. Rawls refers to "an order which requires us to satisfy the first principle in the ordering before we can move to the second, the second before we consider the third, and so on" (Rawls 1971, 43). Such an order is certainly not lexical, and to call it serial or logical would not be adequate. It is in fact transcendental because we are reconstructing the principles which make second and third terms and so on possible. These principles are transcendental because they constitute a necessary condition for the subsequent terms (Illies 2003, 35). For Rawls, a lexical approach does not "seem very promising" (Rawls 1971, 43), although he thinks that a contextualised ordering makes sense to the extent that "at least in certain social circumstances" a serial ordering of principles offers a solution to priority problems (Rawls 1971, 44). It is this contextualism which impedes a hierarchical reconstruction of the transcendental structure of rights in Rawls' theory of justice. In his Political Liberalism, the problem of the priority of liberties is still not based on the idea of such a hierarchy (Rawls 2005, 289-372). It is, however, clear that his idea of an 'Original Position' already presupposes a lot of principles such as that of equality, reciprocity and consensus, which point towards a preliminary hierarchy of principles (Rawls 2001, 18-39).

Closer to the transcendental approach are modern foundational efforts bringing back human rights to a certain first transcendental value implicitly incorporating all human rights. The hierarchical development of human rights as sketched in this paper has to be read in this tradition. In his discussion of the formulation of human rights in the eighteenth century, Ernst Cassirer's neo-Kantian approach takes the right to personality to be the ordering principle of the whole set of human rights. He states that this right "in a certain way incorporates all other human rights" (Cassirer 2002, 230). The reconstruction of such an original element, which gives rise to a series of concatenated rights, is what constitutes the transcendental approach. This first transcendental right- $\mathrm{a}$ sphere that encloses all other rights - determines what has been called the 'right to human rights' (Brunkhorst and Köhler 1999, 7-9). In this way, Hannah Arendt's idea of

\footnotetext{
${ }^{3}$ For a historical overview of the generational dependency of charters, declarations and conventions, see Ludwig Watzal (2004).
} 
a right to rights (Arendt 2000,614) could be interpreted in a transcendental sensewhich is certainly not the way Arendt herself looked at human rights at all. Arendt refuses to take human rights as an innate natural law and takes human rights to be at the social level of civil rights and cultural constructions. Because she refuses to think in a transcendental way her right to rights falls into a foundational gap, it cannot be a cultural right itself, but it is left unclear what status is to be given to such a fundamental right. Arendt claims that it is based on intersubjective relations, but of course by saying this Arendt can only explain its genetic (historical) appearance and not the legitimation of the claim of its universal validity — which in my view constitutes the domain of the transcendental.

If the social domain is not defined by such a domain of transcendental principles, it would be reduced to mere empirical facts - but then, we would not be able to understand the validity claim of norms. We cannot move directly from descriptive sentences to normative claims, and no social sphere of human relations can, as long as it is taken empirically, induce us to understand the internal validity of normative claims. The encounter of the Other in the phenomenological (and quasi-theological) sense of Martin Buber (1983) and Emmanuel Levinas (1972) escapes this empirical descriptive level because the phenomenon of the Other is always in some way transcendental. The idea of the transcendental points to an a priori which is beyond the empirical but which in a way also incorporates the phenomenal since it makes the experienced world possible. The transcendental therefore cannot really be described without recourse to the phenomenal world. In fact, this is already the case in Immanuel Kant's approach to transcendentalism.

There is no way to discover the transcendental domain independently from any empirical basis, but it does not follow from here that we cannot escape the descriptive level of the phenomenal world or that the a priori is in itself empirical. In order to discover a transcendental principle like Cassirer's right to personality or Arendt's right to rights, we have to jump from the phenomenal world to the transcendental domain which enables normativity. The order of normativity is different from the empirical or descriptive order, but norms and rights always apply to descriptive things, so jumping never means abandoning the empirical domain. That is why traditional philosophy chose to seek an intermediary through an analysis of the essence or 'deep nature' of things - in the case of human rights through an analysis of the essence of human beings. In this sense, we have to return to the idea of natural law that Arendt abhorred and sought to escape, but we must keep in mind that we are transcending the descriptive level of empiricism and getting into deep reality - the domain of rational principles existing behind things. In the field of moral philosophy, there is probably no way to surmount the gap between the descriptive and the normative other than this effort to go beyond empirical nature by reconstructing deep nature or the essences of things, which is more than describing an empirical situation, since we are looking for a differentia specifica linked to normative principles. The essence of a human being would not be a physiological description, as we will see later, but its specific property as it is linked to natural rights. Our rational and dialogical nature for example invites us to think the right to free thought to be a natural right.

I am using here the term hierarchy not only in the transcendental sense explained above but also in a more specific transcendental-discursive sense. Empirical-positivistic, pragmatic and sceptical approaches to rights do not depart from such a 
transcendental notion of discursive justification. Here, rights are justified by outer contingencies such as the 'law of the jungle' or the idea of usefulness. But, the term hierarchy, as I use it, is not meant in a political sense as belonging to a theory of power; it refers instead to a vertical ordering of rights that becomes clear as soon as we try to find the implicit argumentative justification of rights through higher principles which incorporate and make possible the lower ones. Hierarchy, therefore, is meant in the sense of an argumentative relation that is always implicit in discursive structures.

This transcendentally discursive sense has been conceptually introduced by Jürgen Habermas' teacher Karl-Otto Apel in order to transcend metaphysical speculations and to reduce the transcendental domain of principles to the implicit domain of pragmatic presuppositions related to speech situations (Apel 1988, 96-99). ${ }^{4}$ According to Apel, the principle of discursivity (that in communicative situations has a transcendental status) entails moral values like individual freedom, equality of rights (Gleichberechtigung), participation in discourse (co-responsibility) and peaceful understanding (Apel 1998, 739, 757). Real dialogue becomes impossible if there is no equality or possibility to participate in discourse. Habermas' interpretation of the principle of discursivity, although it defines itself as being more formal, is still very much structured in Apel's sense. In his theory of right, Habermas does not see this principle as incorporating a set of moral principles and values; he takes it to be a principle which is neutral with respect to morals and justice (Apel 1992, 138; Apel and Kettner 1992). Both Apel $(1998,817)$ and Habermas $(1992,124)$ distance themselves from any attempt to consider human rights to be a natural law, although they acknowledge that human rights are connected to the principle of discursivity that is specific to human nature and especially to human personhood. They start their theories of right from the insight that humans are potentially and by nature (i.e. essentially) dialogical beings capable of rational communicative action. It seems then difficult to deny that there is a link to the idea of natural law since it is this human dialogical nature (man's discursivity) which grounds normativity and rights. Habermas relates human rights to what he calls a preliminary principle of democracy, but this is itself an inflection of the principle of discursivity as conceived in its political orientation (Habermas 1992, 139; Pinzani 2000). All theoretical efforts to explain human rights in a pragmatic sense seeking a kind of agreement, as being linguistic (Alexy), procedural (Rawls), consensual (Habermas) or contractual (Höffe), presuppose a certain universal rational and dialogical nature of the human being. The act of declaring something to be valid can be unanimous, but only a rational justification of rights that discovers transcendental principles can demonstrate them to be so (Forst 2015, 109).

It is in Apel's (1988, 1998) discursive sense, I think, that Rainer Forst (2007) implicitly and Vittorio Hösle (1997) explicitly address the idea of transcendentalism. ${ }^{5}$ Forst takes the right to justification to be the original right encompassing all other human rights. Every human being explains his own actions and the actions of others as being part of a structure of possible justifications. Without these justifications, a person

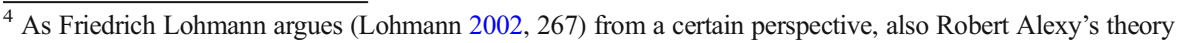
of juridical argumentation (1978) can be interpreted as a discursive transcendental approach to the system of rights. The argumentative capacities constitute the rational potential and therewith the nature of man (Lohmann 2002, 272).

${ }^{5}$ Forst is more explicit about transcendentalism in Normativität und Macht [Normativity and Power] (Forst 2015, 33).
} 
cannot interiorize her actions as being hers. This right to justification seems just to be another formulation for a more fundamental right that in my view should be called a right to dialogue and rationality. Forst starts from the idea of people as being rational and dialogical beings whatever cultural differences there may be among them (Forst 2007, 299). For Hösle, the idea of human rights presupposes the idea of fundamental rights belonging to the essential nature of human beings (Hösle 1997, 594). This essential nature is what constitutes human dignity, which for Hösle - very much in line with Cassirer - is the primary fact of being a person (Hösle 1997, 358). To be a person means to have a self-consciousness that is potentially able to recognize other self-conscious beings as moral objects of its actions. This recognition in fact implies an internal dialogical predisposition entangled with self-consciousness. The essence or deep nature of man is therefore personality which implies the right to be a person in its fullest form. Hösle is also explicit about the need to revaluate the idea of natural law and emphasizes the need to grasp the idea of the hierarchy of human rights (Hösle 1992 35; Hösle 1997 1015). A hierarchically elevated right, as for example the right to political participation, according to him can only be developed at certain levels of cultural development which means that there is, as Hegel acknowledged, a correlation between the levels of cultural development and the recognition of specific human rights.

In this paper, I will try to uncover the implicit hierarchy of human rights starting from a philosophical approach inspired by the transcendental tradition of thought. In this tradition, human rights can be understood to be part of a system of right which is structured hierarchically. As Otfried Höffe points out, from Kant onwards, a transcendental system of right means a rationally jointed and organically structured whole, and certainly not just a lexically or serially clustered whole (Höffe 1981, 338; Brandt 1981). A system of right is a system in which rights are derived from higher principles, themselves based on prior first or ultimate principles and in which fundamental transcendental rights serve to explain or derive other rights that in their focus can be more local or contextual. In this sense, Kant's Metaphysics of Customs (1797) is already programmatic since it develops the principles of right as organically enclosed in the categorical imperative, which in my view is a first principle that in Kant's Groundwork of the Metaphysics of Morals (1785) lacks a satisfactory argumentative foundation since it presupposes an idea (and ideal) of humanity that needs further development in what should be called a transcendental anthropology. ${ }^{6}$

If human rights are part of a system of right, this means that they themselves are structured in the same manner: There is a set of transcendental human rights incorporating all possible specific and more contextually elaborated human rights. I think this becomes clear if we take the Universal Declaration of Human Rights (1948) as an example and reduce its articles to a set of fundamental rights that are transcendental in the sense of constituting an a priori domain that enables the discursive possibility of the specific rights deployed in the Declaration. The claim is that this discursive a priori is already implied whenever we talk about human rights.

\footnotetext{
${ }^{6}$ Such an anthropology is not the object of Kant's later anthropological writing (Anthropologie in pragmatischer Hinsicht, 1789) which was conceived in order to contextualize the idea of morality (Jörissen 2002, 159).
} 
Again, 'a priori' here does not mean that these principles or rights have no link to the empirical world. Rather, it means that these principles or rights must be discursively presupposed once we talk about specifically formulated rights. Reconstructing the transcendental layer of primary human rights comes then to an act of making those things 'explicit' - as Richard Brandom (1994) would call it — which discursively have a preliminary ideal existence. This layer should then constitute the ideal domain of rights defining all possible lists and formulations of human rights. The dependence of any specific human right whatsoever on a set of transcendental human rights, which in their turn - together with other possible rights such as non-human rights - depend on higher transcendental principles of righteousness, shows that the system of right is structured in a hierarchical way. The importance of reconstructing hierarchical structures may be clear by now. In the first place, it is important for a theory of justification of rights to surmount historical relativism, giving an alternative to power-centred or pragmatic theories, and committing to an approach that reduces discursive arbitrariness. In the second place, hierarchical structures are important for action theory, when it comes to prioritizing actions. We need to know how principles of action are hierarchically structured. Awareness of the hierarchical relations helps also to decide in case of dilemmas and collisions of principles. Whether we should rescue a person instead of many, an animal instead of a human being; whether we should choose between transparency or privacy - all these questions involve hierarchical structures of principles. Of course, the questions also involve contextual knowledge, but this kind of knowledge only adds to the given facts - and from facts we cannot directly jump to norms. Contextual knowledge again always requires hierarchically ordered principles valuing the contextual facts. Also, in political action, the study of discursive hierarchy confronts us with an implicit order of priorities that manifests a necessity that is often neglected in politics. Over the last century for example, politics has learned that the raison d'état should be limited by human rights and that these have to be prioritized.

After these long preliminary remarks, I will develop the idea, already partially outlined, that human rights need to be rooted in a philosophical justification based on a transcendental anthropology. This also implies the necessity of revaluating the idea of natural law. A transcendental anthropology is a reflection on the nature or essence of humans that allows for a reconstruction of transcendental norms related to that particular type of nature. Such foundationalism implies a hierarchical structure of justification that constitutes parts of a system of right (On Natural Law and Transcendental Anthropology). This then constitutes a necessary basis to explain the idea of the hierarchy of human rights. After developing a set of schematized ultimate human rights, I will show how the combination of these basic rights can be used to generate the most important articles of the Universal Declaration of Human Rights (The Table of Transcendental Human Rights). This will finally bring us to a short exposition of some important practical consequences for modern ruling elites related to this theoretical exercise (Some Consequences for a Theory of Action).

\section{On Natural Law and Transcendental Anthropology}

Human rights are based on a certain universal idea of human dignity, and this idea is in turn based on a general view of man (Wetz 2011; Dworkin 2011). To declare the cultural relativity of human nature, as Donnelly does when he states that the concept of being 
human "is of no moral significance" (Donnelly 1984, 404), comes down to giving up the possibility of determining universal human dignity. A philosophical anthropology is one of the fundamental pillars of modern law. The discourse on human nature determines what kind of system of law we will have. And vice versa, a specific system of law (e.g. feudal law or national-socialist law) presupposes a certain image of the human. This dependency of the system of law on the view of human beings implies that a system of law is never just an arbitrary expression of power but is founded on deeper ideas. Seen from a deductive transcendental approach, all forms of legitimate positive (domestic and international) law, whether civil, criminal, or constitutional, depend on a transcendental anthropology that constitutes the basis of the idea of human dignity. Of course, this does not apply to the system of right in general: human rights, from which civil rights are derived by way of a philosophical justification, can only be considered to be a part of natural law, next to animal rights and the rights of other living and even non-living creatures.

What natural law means is of course highly controversial (Lohmann 2002, 408), but I am assuming that these rights are inherent in the idea of things as phenomena in nature. They belong to living nature: to animals because of their animal nature, to humans because of their human nature. Natural law is therefore not based on empirical grounds but on the idea expressed by these natural objects. When Kant uses the expression of natural law in his Metaphysics of Customs, he means laws that can be known by reason as being a priori (A 24). Natural law in this sense is a law of reason (Naturrecht=Vernunftrecht). According to Marcel Niquet (2002), there is an implicit transcendental anthropology in Kant's grounding of morality since he starts from the idea of mankind's rationality as constituting our autonomy and dignity. To Kant, man is a citizen of two worlds (the phenomenal and the transcendental). According to Niquet's interpretation, this means that human beings by their rational nature are inhabitants of a 'Kingdom of Ends', a perspective on humanity in which each of us belongs to a world of universal norms $(2002,38)$. As inhabitants of both worlds, we are persons. These are beings capable of reflecting on the principle of morality that guides their actions and are thus able to discover what Kant calls the categorical imperative. To become moral, an individual, a group or mankind in general has to develop this inner ability of self-reflection. But, Niquet also points out that Kant does not deduce from this idea of man's rationality any substantial normative content $(2002,18)$.

In order to escape the Kantian interpretation of an a priori which is too formal (and too separate from the empirical) in Über die wissenschaftliche Behandlungsarten des Naturrechts [On the Scientific Ways of Treating Natural Law] (1803), Hegel shows that a transcendental natural law results from the reconstruction of the essence or Begriff (the constitutive concept) of a thing (Hegel 1986a, II, 461, 503). Things are considered to be both conceived by a mind and expressing a non-empirical deeper reality. They are not just empirical things; they are an inner activity in which imperceptible forces, laws, ends, intentions, volitions, etc., come to the foreground. It is in this living interiority (489), in this domain of ideality (454), that according to Hegel, the system of right (System der Sittlichkeit) is to be found (503/504). Hegel conceives the system of right both as manifesting itself in the individual (Sittlichkeit des Individuums) and in a totality, as an absolute system of right (absolute Sittlichkeit, 504). The Idea of Totality according to Hegel floats (levitates) over the different development stages of the natural world (523). More exactly, the system of right does not levitate above things, it constitutes the inner part of things. This is what Hegel tries to express with the following rather poetic sentence: "The System of Right is the unfolded flower of the 
folded celestial system" (503). ${ }^{7}$ And, in his Phenomenology, Hegel shows us that to overcome Kant's formal transcendentalism, we need to consider the immanent content of things, we need to analyse things from 'inside', that is, to analyse their 'inner life' (Hegel 1986b, III, 52). ${ }^{8}$

Seen from this transcendental perspective which takes natural law to be the basis of human rights, the designation Universal Declaration of Human Rights is not really an adequate expression of the claim that is inherent in these rights. In the preamble and in the first two articles of the Declaration, there are hints pointing towards what in traditional philosophy is called natural law, since it is acknowledged that the rights considered in the Declaration have their basis in a general human nature. The preamble speaks of 'an inherent dignity' and of 'inalienable rights' that human beings have just because they are human and that they have by virtue of their nature. The first article mentions the innate equality in 'dignity and rights' due to the rational and moral nature of humans: "They are endowed with reason and conscience and should act towards one another in a spirit of brotherhood". In the second article, the relationship between man's rights and man's being and nature is again reaffirmed by emphasizing that social and biological differences such as race, colour, gender, language and religion do not affect what is given to human beings by way of birth. The formulation of the preamble and the first two articles do not leave much room for positivistic, pragmatic and sceptical interpretations of human rights. The wording makes it clear that the Universal Declaration of Human Rights should actually be called the Declaration of Universal Human Rights. This shift of the adjective in the title would show that the universality of the Declaration is ultimately not derived from procedural or consensual grounds alien to the idea of transcendental natural law. Transposing the adjective would reveal that the Declaration is not just an agreement, but that it presupposes philosophical grounds locating human rights in a hierarchical structure of transcendental principles. An important disadvantage of all theoretical approaches based on pragmatic and consensual grounds is that they randomly stop the discursive foundational process and provide no insight into the hierarchical structure of law (the system of right). When law is based on mere agreement - as the consensual pragmatists claim, or on power decisions as the postmodernists do - then the connection between the different hierarchical layers of law becomes arbitrary. In a transcendental approach, human rights would turn out to be a subordinate part of natural law, and institutionalized rights (positive law) would turn out to be subordinated to transcendental human rights, which constitute the basis of any possible declaration concerning the rights of human beings.

The natural law theory I am proposing here is a transcendental one, based on an essence analysis of phenomenal things. Human rights are based on a transcendental anthropology that elucidates the dignity of mankind. This anthropology should be constructed in such a way that all possible human rights might be derived from

\footnotetext{
7 "So ist in dem Systeme der Sittlichkeit die auseinandergefaltete Blume des himmlischen Systems zusammengeschlagen" (1986, II, 503).

${ }^{8}$ A more sophisticated explanation of phenomenological essence analysis has been developed in Edmund Husserl's 'Wesenschau' in Ideen I (Brauner 2008, 6-9).
} 
it following a specific order. Within the scope of this paper, I cannot enter into specific discussions related to other proposals of transcendental anthropology. ${ }^{9}$ I am aiming to show here some of the ideas necessary for an understanding of how a system of rights can be deployed. As I have discussed above, the differentia specifica of humans is personhood. The word 'person' is meant in the sense of potentially being a rational being with deep feelings - a so-called inner soul—on which it is itself able to reflect. This is a being potentially having a complex and developed dialogical capacity. The fact that person in Latin originally meant mask underscores the idea of a deeper reality existing behind the surface of the body and communicating through it to others (this act was called 'personare').

The existence of personhood is something we cannot deny without implicitly recognizing its existence. Indeed, it would in fact imply a pragmatic contradiction to deny personhood, since we declare ourselves to be persons from the moment we speak. The rights of humans are rights guaranteeing the possibility of developing this inner potentiality of personhood. They support the existence of institutional layers enabling persons to develop their individual personalities. The core elements of a personalist theory of human rights have been summarized by Hegel and Karl Popper, although they reappear in different ways in several philosophical anthropologies in the history of thought, perhaps starting with Plato's tripartite theory of the human soul. Human rights were developed in a historical process of thought that Hans Joas, following Ernst Troeltsch (2002), describes as the sacralisation of the person, for which religious developments such as Christianity were crucial $(2011,96)$. Notwithstanding important differences between Hegel and Popper, both emphasize the fact that humans are a unity of three dimensions: body (sensitivity), consciousness (psyche) and rational selfawareness (self-reflection or spirit). Hegel calls these three dimensions the 'Ansichsein' (being-in-itself), 'Fürsichsein' (being-for-itself) and 'Andundfürsichsein' (being-inand-for-itself) (Hegel 1986b, III, 28-31). Popper speaks of three dimensions of the human, related to his 'manifold worlds theory' (Popper 1978, 143-144). He speaks of 'world 1', 'world 2' and 'world 3'. World 1 refers to man as an object in the world, as a living sentient being, world 2 refers to the world of psychological states, and world 3 is about the products of the mind and thus of intersubjective and cultural products more than of personal self-reflection (Popper and Eccles 1976, 36-51). The relationship between this intersubjective world or 'community domain' (world 3) and selfconsciousness seems to be an obvious one: Being self-conscious is like becoming a community; for in order to become self-conscious, the subject must be able to double itself. Conversely, becoming a community is like being self-conscious since we become able to mirror ourselves in the other. The three dimensions of personhood of course also involve three types of needs, but if we had started with particular empirical needs, this would have implied a naturalistic fallacy since we cannot distil norms or rights from

\footnotetext{
${ }^{9}$ I have already referred to important differences in this field: Apel's (1992) and Alexy's (1983) discursive transcendental approaches are different from Höffe's transcendental contractualism, and all these are different from cosmological approaches such as those of Max Scheler (1928) or Harald Holz (1973), and existentialist approaches (Martin Heidegger 1927; Thomas Rentsch 1990) or theological ones (Wolfhart Pannenberg 1995). There is a possibility of recognising the truth aspects of all these approaches, but the idea of personhood in my view is central to such a synthesis. Contractualism already implies discursivity and personhood, and it makes no sense to develop an existentialist or theological approach to transcendental anthropology if we abstract it from the very idea of personhood, since it is only the person who really 'exists' and believes religiously.
} 
mere empirical facts. I have therefore first reconstructed the essence of man, the layers of the a priori idea of personhood, to which our primary needs can be related. The transcendental rights of man can be summarized in a table using $x-y$ coordinates deploying on the one hand the core elements of personhood and on the other the worlds involved by it.

\section{The Table of Transcendental Human Rights}

It is important to recognize that despite the many differences between existing positions in transcendental anthropology, none of them can get away from the importance of these three layers of personhood. In Table 1 , I have schematically visualized transcendental rights that originate from the philosophical anthropology discussed above and the fundamental right to personhood implied by it, which means that our human essence implies a set of fundamental rights. The three dimensions of personhood also involve specific needs, as I said above, but these needs cannot be taken as mere empirical facts since they are here part of the essence of personhood. The separation of mental and spiritual needs might not at first glance be immediately obvious. The difference becomes clear as soon as their corresponding rights are considered — which are shown in rows 2 and 3 . The rights of the first row refer to what Shue, starting from an empirical reconstruction, called 'subsistence' and 'security', as being the most basic human rights (1996, 30).

In the first white column, we encounter all those transcendental rights (right to nourishment, to freedom and to duty) that constitute the basic essence of personhood, unpacked as objective nature (the sentient body), subjective mind (the psyche) and objective spirit (our consciousness objectivizing itself). Starting from the horizontal reading of the table, the idea is that if these natural basic rights of personhood were lacking, then the rights of columns 2 and 3 could not seriously be developed. The right to nourishment (cell 1) constitutes the basic condition of all rights related to our physical nature: It makes no sense to guarantee the right to housing and to health (cells 2 and 3) if the right to nourishment (subsistence) was not

Table 1 Transcendental human rights

\begin{tabular}{|c|c|c|cr|}
\hline $\begin{array}{c}\text { Wentient } \\
\text { body } \\
\text { (Physical } \\
\text { Needs) }\end{array}$ & $\begin{array}{c}\text { Nature } \\
\text { (world 1) }\end{array}$ & $\begin{array}{c}\text { Nourishment } \\
\text { (Life) }\end{array}$ & $\begin{array}{c}\text { Subject } \\
\text { (world 2) }\end{array}$ & $\begin{array}{c}\text { Housing } \\
\text { Intersubjectivity } \\
\text { (world 3) }\end{array}$ \\
\hline $\begin{array}{c}\text { Consciousness } \\
\text { (Mental } \\
\text { Needs) }\end{array}$ & Freedom & 4 & Health \\
(Care)
\end{tabular}


acknowledged in the first place. The right to freedom (cell 4) constitutes the basic condition of all rights related to our psyche. It is the central right of our inner life. If there were no freedom, then learning (cell 5) and communicating (cell 6) would lose their value: It makes no sense to acknowledge the right to education and to communication if the right to freedom is ignored. The right to education and the right to express oneself are both extensions of human freedom. An educational system or a public sphere that ignores man's fundamental freedom ignores its own basis. The right to duty (the right to exercise our duty-cell 7) constitutes the basic condition of all rights related to our spiritual nature. Duty is the cornerstone of the self-conscious spirit and necessary for the development of morality. Self-consciousness links every right to a specific duty. A feeling of duty arises when consciousness is aware of itself and its tasks. As between freedom and consciousness, there also exists a natural connection between self-consciousness and duty. Once the subject is conscious about itself, its own actions become a particular object of consideration. This duty towards itself (cell 7) is reflected in self-formation (cell 8). The duty towards society is reflected in participation (cell 9). It makes no sense to acknowledge the right to selfformation (Bildung) and to active participation in society, if we are impeded in the development of an active awareness of our duties.

In a similar way, the transcendental rights of column 3 presuppose a serious acknowledgement of those stated in column 2: The right to health (cell 3) makes no sense if the right to housing and shelter (cell 2) is ignored; the right to communication (cell 6) cannot be guaranteed if the right to education (cell 5) is not taken seriously; and the right to democratic participation (cell 9) loses all value if people are not acknowledged in their right to flourish (cell 8). A vertical reading of Table 1 shows a similar dependency. The right to duty lacks any sense if the rights to freedom (cell 4) and subsistence (cell 1) are ignored. Self-formation (cell 8) makes no sense without education (cell 5) and a safe habitat (property and shelter) for the individual protecting and supporting its subjectivity (cell 2). And, political participation (cell 9) cannot seriously be conceived if people have no right to health (cell 3), that is to support in the case of ill health, and if people have no right (to use the means) to communicate with others (cell 6).

In the second white column, we find those rights that strengthen or protect the individual subject. The right to shelter (housing, lodging but also property - cell 2) should be taken in an extensive sense, including also, for example, the right to dress or the right to the use of things. The right to learning (cell 4) should also be understood in an extensive way and does not necessarily relate to our modern institutional educational system nor does the learning process need to be by definition intersubjective. The object of education and self-formation is always the subjectivity which constitutes our individuality. We can learn from nature (from animals for example), and life experience is also an important teacher. The right to self-formation or development (Bildung) is a matter of self-awareness and selfconsciousness and implies a certain circular movement (self-reflection), whereas educational learning is linear, based on a continuous interiorizing of learned things. I have already mentioned the horizontal relationship between, respectively, the right to shelter, to education and to self-formation and the right to health, communication and participation. The right to healthcare (cell 3) could not be guaranteed if there were no right to shelter (cell 2), developing a kind of second skin of things around the subject. The right to communication (cell 6) means nothing if there is no right to education (cell 5). And, the same can be said for the right to participate in shaping society (cell 9): This would make little sense if people did not learn to make use of their right of self-formation (cell 8). The vertical reading of column 
2 shows that this right of self-formation very much depends on the acknowledgement of the right of education because no serious self-relation would be possible if the subject had not acquired certain basic knowledge by educational means. People would not be able to develop if they were deprived of the possibility of learning. The right to educate our own inner world (cell 4) would make little sense if there was no right to protect our subjectivity from the erosion of the physical world (cell 2).

In the third white column, we find genuine intersubjective rights. The right to healthcare (cell 3) primarily concerns not only our physical body but also includes the need for our psychic health to have a physical expression. The intersubjective element of this right resides in the inability of the subject to take care of itself when health is at stake. Health is seriously compromised if it cannot be guaranteed intersubjectively. Rights related to psychological healthcare are already on the edge of cells 3 and 6 since they often imply situations of blocked communication. Our right to communication (cell 6) starts with our right to bodily expression (of which speech is just a form) which is a first form of our right to dialogue. It includes the right to have access to other subjects and hence to the means needed for that end. It is on this level that we must situate Forst's right to justification. Contrary to his view, this is not the highest and most fundamental right of human beings (Forst 2011, 54) but a variation of the basic transcendental right to communication. Communication is an act between subjects, but what is externalised here is the subject itself. The subject offers itself to others. With the right to political participation (cell 9), the individual is acknowledged as being a co-creative member of the community. This is a formation that is not directed towards the self but towards the community to which this self-consciousness belongs. Of course, it would make little sense to acknowledge the right to participation if there was no right to express oneself (cell 6), and it would make no sense to guarantee the right to communicate (cell 6) if we were not secured in our basic right to health (cell 3).

A diagonal reading of Table 1 also indicates a hierarchy. The right to nourishment or life (cell 1) is the most elementary right; the right to full participation in shaping society (cell 9) is the most elevated one. This hierarchy is transcendental in the sense that the right to nourishment is a necessary condition for all the other rights of the table - and also in the sense that the more elementary rights develop towards the higher rights. The rights of the first and second horizontal rows can therefore never be ends in themselves; they find their ends in the rights of the third row, which in itself is also hierarchically structured towards the highest right of communal co-creation.

Table 1 is an attempt to create a categorical baseline from which the rights of humans, as in the Universal Declaration of Human Rights, could be derived following a transcendental foundational line. It creates a window to the hierarchical structure underlying the specific rights formulated in a document with no systematic ambition in itself. In this document, there seems to be a very limited attempt to systematize the formulated rights by starting with those articles that are related to the physical condition of man. This and some existing groupings of rights ${ }^{10}$ seem to indicate that there is an implicit notion of ranking in the Declaration. The document, however, remains a loose list of articles with no serious attempt at systematization.

Article 3, which is actually the first real article of the list, and articles 4, 5 and 25 emphasize (although not exclusively) rights relating to the physical condition of people.

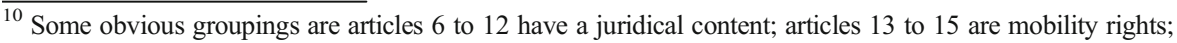
articles 16-17 and 23-24 are rights focusing on civil law (family, property and labour rights).
} 
Article 3 speaks of the right to life, which is in fact equivalent to the right to nourishment (cell 1) because life depends on nourishment. Labour, being the basic right of the economy (as mentioned in article 23 and 24), can be derived from cells 1 (Life) and 2 (Housing) because labour is about survival and about adapting the environment to protect and facilitate the inner world. The right to marriage and to start a family (article 16) can be linked to the need to procreate, the right to life of new generations (cell 1), the need for safety and shelter (cell 2), and the need to build a stable community of communication (cell 6).

Article 25 includes the right to clothing and housing on the one hand and to health on the other: In fact, it marks the relation between cell 2 and 3 of Table 1 . The right to property (article 17) can be derived from the second cell of the table, the transcendental right to housing, property just being a skin of things in the outside world protecting and facilitating the existence of a subject. The right to asylum (article 14) can be deduced from a combination of the transcendental rights to housing and to freedom. If we naturally stretch the meaning of housing, then we can also derive the right to nationality (mentioned in article 15).

Article 4 on the prohibition of slavery clearly refers to the transcendental right to freedom (cell 4), but the ban on slavery also relates to violations of bodily integrity, like article 5 on the prohibition of torture. Both slavery and torture neutralize the transcendental right to healthcare (cell 3) and, in the worst case, the right to life (cell 1). The right to the inviolability of the person mentioned in article 3 of the Declaration can be derived from the transcendental rights to life (cell 1) and to freedom (cell 4), the person being both the body and the free will. In fact, the person is also the ability to reflect upon itself, thus becoming a moral entity whose inviolability includes the right to exercise its duties (cell 7). The right to privacy (article 12) is linked to these crucial rights to personhood and can be directly derived from the rights to freedom (cell 4) and to duty (cell 7).

Articles 18 and 19 guarantee the rights to think and speak and can be derived from the transcendental rights to freedom and communication (cells 4 and 6). The right to religion, also mentioned in article 18 of the Declaration, is a specific form of our freedom of thought and opinion which is directly derivable from cells 4 and 6 . The right to freedom of opinion should therefore always have priority over the right to religion. There should be no misunderstanding about the hierarchy between these two rights: Without freedom of opinion, there would be no freedom of religion. Related to this transcendental right to communication (cell 6) are also all mobility rights (mentioned in articles 13 to 15) because communication is not only a matter of expression but it is also a matter of transporting and receiving the message and this requires freedom of association.

Other rights of the Declaration, such as article 26 on education, and articles 22 and 27 on self-realization, are direct expressions of the transcendental right to education and selfformation (cells 5 and 8). Article 29 of the Declaration on specific duties of the individual towards the community and towards itself is in fact an expression of the transcendental right to exercise our duties (cell 7). And, articles 20 to 22 describing political rights are direct expressions of the transcendental right to political participation (cell 9).

There are also some articles in the Declaration that, for their derivation, require all the cells of Table 1, for example, the right to welfare (standards of living, article 25) or the right to peace and social security (article 22). These rights are in fact rights to wealth that can be derived from some or all cells of Table 1 depending on which definition of wealth one is using. ${ }^{11}$

$\overline{11}$ On the definition of 'wealth', see Martha Nussbaum and Sen (1993, 30-54). 
The remaining articles of the Declaration, articles 6 to 12 and articles 28 to 30, are special cases with a juridical content defining legal aspects, such as equality before the law, right to legal assistance, prohibition of random treatment in criminal law, and duties of states and individuals towards human rights. These articles can only be derived from the table of transcendental rights if they are combined with higher transcendental principles of justice that I still have to specify.

\section{Some Consequences for a Theory of Action}

The historical development of legislation shows that there are methods of justification other than transcendental discursive foundations. History seems to speak in favour of power-oriented, sceptical and pragmatic approaches to the philosophy of law rather than in favour of the idea of natural law (Joas 2011, 251). ${ }^{12}$ These approaches point their finger at historical facts that are inconsistent with the idea of human rights being rooted in natural law. Indeed, we cannot say that human history is the immediate, successive deployment of the transcendental hierarchical structure of natural law. The dimension of the 'facticity of law', to use a distinction introduced by Habermas (1992, 15-22), does not correspond to the dimension of the 'validity of law'. Yet, we could read the history in such a way that we may recognize in the tumult of events an attempt to bring the facticity of law in line with the validity of law, or as Hegel would have it, to bring the validity of law into the domain of the facticity of law (Hegel 1986c, VII, 25). This attempt to translate the ideal 'discursive foundation' of justice in terms of real institutional structures is one of the key elements of what we used to call social progress.

If we take politics to be the formative principle of society, then we could define politics as the attempt to establish the validity of law. This translation of the realm of ideals into reality presupposes the deployment of a practical conversion of implicit discursive formulations and foundations. The tumult of history and the struggles for power can be seen as an ex post facto process of 'moral learning' with peaks and troughs comprising at least two moments: (1) the moment of the formulation of different rights and (2) the moment of their philosophical justification. To formulate rights in a precise way is certainly essential, but this always presupposes an (implicit) foundation. The importance of this is often underestimated - and I am not only speaking theoretically but also practically. A transcendental foundation of rights always presupposes a hierarchy because it appeals to principles and higher rights serving as a basis for other more specific rights. It is this hierarchy that is often overlooked in politics. The translation of hierarchical 'higher' or 'more basic' rights into practice is often not given the priority it deserves. In this transposition from the validity of the law to reality, priority clauses are violated due to a neglect of the hierarchical aspects of justice which do not find an expression in the formulation and in the political implementation of rights.

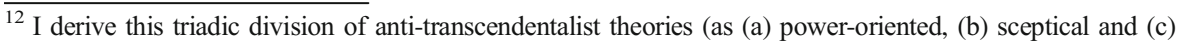
pragmatic) from Ronald Dworkin, who distinguishes between conventional, pragmatic and integrative theories of justice. Power-oriented approaches cover, to a large extent, the conventional theories (Dworkin 1986, 114 150). When Dworkin speaks of pragmatic theories, however, a distinction should be made between sceptical and pragmatic approaches. Dworkin's integrative legal theories fall under the domain of what I have called the discursive approach.
} 
The principle of hierarchy of course touches the problem of priorities. ${ }^{13}$ The hierarchy outlined in Table 1 does not represent a scheme of just pure theoretical subtleties that is of little importance for everyday life. 'Priority' is in fact a translation into the vocabulary of action theory of what hierarchy denotes in terms of a foundational theory. We cannot talk about priorities without thinking about hierarchies. Now, priorities can be inclusive or exclusive. If we focus on one point excluding all other points, then the given priority is exclusive. An inclusive priority has a comprehensive nature because the concentration on one point does not lead to a subsequent neglect of the other points. Exclusive priority starts from an analytic approach, whereas inclusive priority presupposes a holistic method. Human rights are of course a total package. There can be no real justice without a complete implementation of the system of right. Yet, the unfolding of the system of right is a gradual process taking its place in history. To set historically and contextually related priorities means that the inclusiveness of human rights requires strategies and actions of progressive implementation of all the transcendental rights of Table 1 .

Table 2 is a translation of the main levels of Table 1 into the vocabulary of a historically based action theory. In fact, Table 2 summarizes the main global challenges of humanistic engagement in the modern world.

Sustainable development refers to the physical and material basis of our existence and includes such diverse things as genomics and ecology. The most basic human rights need to be framed alongside this concept of sustainability which, through action theory, becomes part of the hierarchic structure of human rights (Marshall and Toffel 2005,673 ). If these rights are severely violated intervention may be required (even leading to possible armed conflicts). From education and communication in Table 1, a line can be drawn to action theory by means of interpersonal and intercultural dialogue. On this level, personal freedom is central - education cannot legitimate coercion, and dialogues cannot be imposed but can only be facilitated. From row 3 in Table 1, a line can be drawn to Table 2 in which duty, self-realization and political participation are translated in terms of a cosmopolitan citizenship. On this level, what must be facilitated is not primarily freedom, but duty. To strive for world citizenship may be a duty, but its basis must be cooperation and can never be coercion (Nida-Rümelin 2009, 339). In particular, 'duty' and 'participation' are responsible for the dynamics of human rights throughout history. These most elevated forms of the system of transcendental human rights are in fact the teleological engine moving forward the implementation and deployment of all rights.

As soon as a society guarantees the right of everyone to (a) carry out their duty (cell 7, Table 1), (b) develop their inner self (cell 8) and (c) fully participate in organizational and governmental politics (cell 9), there will be no real hindrance for subjects (citizens) to respond to their moral obligations and to contribute to an extensive realization of right (including rights of natural law other than human rights). From the moment they become the owners of their own life (cells 7 to 9), these subjects will be carriers of a general and authentic responsibility. Not duty - which like all transcendental rights is in fact incorruptible and always remains the same - but responsibility grows when a person holds a ruling function (self-realization and participation are ruling functions). The implementation of human rights will always primarily depend on what people in

\footnotetext{
${ }^{13}$ It is also in relation to this aspect that Rawls discusses the ranking of law (Rawls 1971, 40-46).
} 
Table 2 Transcendental domains of action

\begin{tabular}{|c|c|}
\hline $\begin{array}{c}\text { Objective } \\
\text { Nature } \\
\text { (world 1) }\end{array}$ & $\begin{array}{c}\text { Sustainable } \\
\text { Development }\end{array}$ \\
\hline $\begin{array}{c}\text { Subjective } \\
\text { Mind } \\
\text { (world 2) }\end{array}$ & $\begin{array}{c}\text { Intercultural } \\
\text { Dialogue }\end{array}$ \\
\hline $\begin{array}{c}\text { Objective } \\
\text { Spirit } \\
\text { (world 3) }\end{array}$ & $\begin{array}{c}\text { World } \\
\text { Citizenship }\end{array}$ \\
\hline
\end{tabular}

charge (governors, administrators, managers and directors) do. In ruling positions, the burden of priority decisions is very heavy. What Table 2 shows is that citizens, especially those in charge, need to look at situations from the perspective of cosmopolitanism if they are conscious of the real weight of the rights of human beings.

The task of deciding on priorities cannot be done without observing the inner hierarchy of the system of right and the clause priorities implied by it. Whatever the office or function of people in charge may be, the realization and observance of these rights belong to their specific primary duties. It took centuries to realize that those ruling over states or companies should not obstruct the realization of transcendental human rights. The victory over exclusivism (especially exclusive nationalism and dictatorship) by the 'idea of democracy' and over raw capitalism by the labour movement made this social progress possible. Meanwhile, it is clear that those controlling states and enterprises should not just refrain from obstructing the system of right but should actively pursue its worldwide implementation. The awareness that is the main duty of those in charge is not only to rule a state or manage a company but also to contribute to the common good by realizing the system of right. This is now slowly becoming an accepted idea.

But, this has some clear consequences for ruling elites. What must be abandoned is a certain tendency to introversion. Extroversion on the contrary is based on the faculty of extending our self to other domains (up to including, next to humanity and living beings, the realm of 'things'). ${ }^{14}$ The ruling style cannot just be managerial, since here, the focus is introverted, directed towards the main task of making sure that a company, state or any organization functions as a well-oiled machine. A universal rights-oriented action radius has no priority when tasks are only formulated in strategic or functionalistic language. A consequence of our reflections on the hierarchy of rights is that the actions of ruling elites should primarily be directed towards the universal implementation of transcendental rights. ${ }^{15}$

\footnotetext{
${ }^{14}$ For an extension of politics, see Bruno Latour (1999).

15 Transcendental rights need not be only human rights: We could also speak of transcendental rights of animals, a subject too extensive to discuss here.
} 
If this is not on the top of the list, ruling a company or a state will just become a question of taking strategic decisions aimed at a maximization of profits or GDP. When they pursue economic growth, this must serve the system of right, which means that it should serve the most elementary rights of all mankind. Although we cannot get into the question of the rights of nature here, it should be clear from what has been said above that the state and in fact any human organization should also put priority on these rights because they are necessary for the subsistence of humanity in general. ${ }^{16}$ Our responsibility towards the system of right therefore knows no inside or outside: We have a responsibility towards both humanity and nature.

The main growth that the state should pursue is a growth of the general implementation of the system of right. There is no reason to think that this does not also apply to companies. There can be no real growth when business profits increase at the expense of the system of right. And, when that happens, the introverted managerial style must be abandoned in order to understand what really has priority. Enterprises should not just avoid getting involved in situations that increase injustice, they should in fact actively fight injustice. This is the essence of what has been called 'Corporate Social Responsibility', but what I am saying here goes far beyond the average understanding of it because it implies that the primary goal of an organization or enterprise has fundamentally changed. The main objective is not to create profits but to enhance justice and to foster an extensive common good, which of course does not mean that the search for profit should be totally abandoned but only that this search is to be subordinated to ethical imperatives serving the implementation of rights. This also means that the point of reference for exemplary action shifts. Seen from this point of reference, organizations such as aid organizations now have an exemplary structure because they are selfreflectively aware of their subordination to ethical principles serving a universal system of right. Economically, they have to subsist, and they can even strive to make some profit, but their fundamental purpose is to serve the universal system of right that embeds both human and non-human rights.

Those who promote the hierarchy of rights will also understand the idea of world citizenship, although, of course, there are other ways to understand it. As a concept, 'citizenship' belongs to the core notions of a theory of civil action which is based on a transcendental theory of justice. In a narrow sense, the word citizenship means that people are bound by the law — by the rights and obligations — of a state (Marshall 1992; Marshall and Bottomore 1992). This definition is conventional and not incorrect. Those who realize that the system of right transcends conventional and national legislation, who take this system to have a transcendental existence (even though it is not always and everywhere explicitly expressed in the idiom of legislation) and who recognize that this transcendental system is hierarchical, will also understand that the conventional definition of citizenship must be extended. A citizen whose sense of duty is oriented towards the hierarchy of rights has become a citizen of a higher order, rising beyond the conventional. This is true cosmopolitism or world citizenship. This is of course an idealization of human beings, but such an idealization is always the case when norms, rights and morality come into play. We hope to comply to our duties although we often fail. We could perhaps speak of deontopolitism (citizenship of the domain of rights)

\footnotetext{
${ }^{16}$ This does not mean that rights of non-human entities must be obeyed only to the benefit of humanity. They must be obeyed per se, but if we focus on human rights (as we do in this paper), then row 1 of Table 1 and cell 1 of Table 2 imply a priority of sustainability issues.
} 
because whereas 'world' denotes a geographical domain, 'right' points to a normative realm of reality. As a 'citizen of the domain of rights', you do not situate yourself on the level of national legislation, nor even on that of acclaimed human rights listed in whatever declaration, because your understanding of the world is a transcendental one. The world citizen observes the world from this higher position of transcendental rights and principles. Here, we are citizens of Kant's essentially non-material Kingdom of Ends. To make this step towards world citizenship may be a personal decision, but it requires an understanding of hierarchy as a core principle of justice.

\section{Conclusions}

I have shown that a transcendental approach to rights opens a way to understanding the hierarchy that is inherent in human rights. It is precisely this hierarchical aspect which has been underestimated - to the point of being almost neglected - in modern human rights theory. To a certain extent, this corresponds to a confusion of the priorities that dominate modern realpolitik, as much on the level of state rule as on the level of corporate leadership. Contributing to the common good or what some now call Corporate Social Responsibility is not just the awareness that strategic or functionalistic thinking must be accompanied by an orientation towards rights, it is moreover the awareness of the importance of implementing the transcendental system of right. If we want to understand the growth of critical consciousness in modern societies, a growth that is sometimes summarized in terms of 'moralization of the markets' (Stehr Stehr et al. 2009) but that in fact denotes a 'moralization of society', we need to open human rights theory to an approach much more centred on the idea of the hierarchy of rights. I have developed here an attempt to understand the necessity and the internal order of such a hierarchy, and I have clarified the system of transcendental human rights from which any set of specific human rights such as those formulated in the Universal Declaration of Human Rights - or any other document — can be derived. A deep awareness of this hierarchy could transform the task of modern politics.

Open Access This article is distributed under the terms of the Creative Commons Attribution 4.0 International License (http://creativecommons.org/licenses/by/4.0/), which permits unrestricted use, distribution, and reproduction in any medium, provided you give appropriate credit to the original author(s) and the source, provide a link to the Creative Commons license, and indicate if changes were made.

Publisher's note Springer Nature remains neutral with regard to jurisdictional claims in published maps and institutional affiliations.

\section{References}

Alexy, Robert (1983), Theorie der juristischen Argumentation, Suhrkamp, Frankfurt/M (1978).

Apel, Karl-Otto (1988), Diskurs und Verantwortung, Suhrkamp, Frankfurt/M.

Apel, Karl-Otto (1992), Diskursethik vor der Problematik von Recht und Politik, in: K.-O. Apel \& M. Kettner (1992), 29-62.

Apel, Karl-Otto (1998), Auseinandersetzungen, Suhrkamp, Frankfurt/M. 
Apel, Karl-Otto \& Kettner, Matthias (eds. 1992), Zur Anwendung der Diskursethik in Politik, Recht und Wissenschaft, Suhrkamp, Frankfurt/M.

Arendt, Hannah (2000), Elemente und Ursprünge totaler Herrschaft, Piper, München (1951).

Brandt, Reinhard (ed. 1981), Rechtsphilosophie und Aufklärung, De Gruyter, Berlin.

Brandom, Richard (1994), Making it Explicit, Harvard UP, Cambridge (Mass).

Brauner, Wolfgang (2008), Kant und Husserl und die Idee einer transzendentalen Anthropologie, in: www. geistundkultur.de/kant_husserl_ant.pdf.

Brunkhorst, Hauke, Köhler, Wolfgang \& Lutz-Bachmann, Matthias (eds. 1999), Recht auf Menschenrechte, Suhrkamp, Frankfurt/M.

Buber, Martin (1983), Ich und Du, Schneider, Heidelberg (11957).

Cassirer, Ernst (2002), Vom Mythus des Staates, Meiner, Hamburg (1946).

Donnelly, Jack (1984), Cultural Relativism and Universal Human Rights, in: Human Rights Quarterly, 6/4, 400-419.

Donnelly, Jack (2002), Universal Human Rights in Theory and Practice, Cornell UP, Ithaca.

Dworkin, Ronald (1986), Law's Empire, Fontana, London.

Dworkin, Ronald (2011), Justice for Hedgehogs, Harvard UP, Cambridge (Mass).

Farer, Tom (1992), The Hierarchy of Human Rights, in: American University Journal of International Law Review, 8/1, 115-119.

Fichte, Johann Gottlieb (1971), Grundlage des Naturrechts, De Gruyter, Berlin (11796).

Forst, Rainer (2007), Das Recht auf Rechtfertigung, Suhrkamp, Frankfurt/M.

Forst, Rainer (2011), Kritik der Rechtfertigungsverhältnisse, Suhrkamp, Berlin.

Forst, Rainer (2015), Normativität und Macht, Suhrkamp, Berlin.

Habermas, Jürgen (1992), Faktizität und Geltung. Beiträge zur Diskurstheorie des Rechts und des demokratischen Rechtsstaats, Suhrkamp, Frankfurt/M.

Hegel, Georg Wilhelm Friedrich (1986a), Über die wissenschaftliche Behandlungsarten des Naturrechts, vol. 2., Suhrkamp, Frankfurt/M (1803).

Hegel, Georg Wilhelm Friedrich (1986b), Phänomenologie des Geistes, vol. 3, Suhrkamp, Frankfurt/M (11807).

Hegel, Georg Wilhelm Friedrich (1986c), Grundlinien der Philosophie des Rechts, vol. 7, Suhrkamp, Frankfurt/M (11833).

Heidegger, Martin (1927), Sein und Zeit, Niemeyer, Tübingen ( $\left.{ }^{1} 1927\right)$.

Höffe, Otfried (1981), Kants Begründung des Rechtszwangs und der Kriminalstrafe, in: R. Brandt (1981), 335-399.

Holz, Harald (1973), Mensch und Menschheit. Entwürfe zur Grundlegung und Durchführung einer philosophischen Anthropologie, Bouvier, Bonn.

Hösle, Vittorio (1992), Praktische Philosophie in der modernen Welt, Beck, München.

Hösle, Vittorio (1997), Moral und Politik, Beck, München.

Illies, Christian (2003), The Grounds of Ethical Judgement, Oxford UP, Oxford.

Joas, Hans (2011), Die Sakralität der Person, Suhrkamp, Berlin.

Jörissen, Benjamin (2002), Anthropologische Hinsichten, pragmatische Absichten Kants >Anthropologie in pragmatischer Hinsicht und ihr Bezug zur Anthropologie des Pragmatismus, in: Paragrana, 11/2, 153176.

Klein, Eckart (2008), Establishing a Hierachy of Human Rights. Ideal Solution or Fallacy?, in: Israel Law Review, 41, 477-488.

Koji, Teraya (2001), Emerging Hierarchy in International Human Rights and Beyond. From the Perspective of Non-derogable Rights, in: European Journal of International Law, 12/5, 917-941.

Latour, Bruno (1999), Politiques de la nature, La Découverte, Paris.

Levinas, Emmanuel (1972), Humanisme de l'autre home, Fata Morgana, Paris.

Lohmann, Friedrich (2002), Naturrecht und Partikularismus, De Gruyter, Berlin.

Marshall, Julian \& Toffel, Michael (2005), Framing the Elusive Concept of Sustainability. A Sustainability Hierarchy, in: Environmental Science and Technology, 39/3, 673-682.

Marshall, Thomas H. \& Bottomore, Tom (eds. 1992), Citizenship and Social Class, Pluto, London ( $\left.{ }^{1} 1949\right)$.

Marshall, Thomas H. (1992), Citizenship and Social Class, in: T. H. Marshall \& T. Bottomore (eds.), 8-17.

Maslow, Abraham (1954), Motivation and Personality, Harper \& Row, New York.

Nida-Rümelin, Julian (2009), Philosophie der Lebensform, Frankfurt/M.

Niquet, Marcel (2002), Moralität und Befolgungsgültigkeit, K\&N, Würzburg.

Nussbaum, Martha \& Sen, Amartya (1993), The Quality of Life, Oxford UP, Oxford.

Pannenberg, Wolfhart (1995), Was ist der Mensch? Die Anthropologie der Gegenwart im Lichte der Theologie, Vandenhoeck \& Ruprecht, Göttingen. 
Pinzani, Alessandro (2000), Diskurs und Menschenrechte. Habermas' Theorie der Rechte, Kovac, Hamburg. Popper, Karl R. \& Eccles, John C. (1976), The Self and Its Brain, Springer, Berlin.

Popper, Karl R. (1978), Three Worlds, Tanner Lecture, in: tannerlectures.utah.edu/lecture-library.php.

Rawls, John (1971), A Theory of Justice, Harvard UP, Cambridge (Mass).

Rawls, John (2001), Justice as Fairness, Harvard UP, Cambridge (Mass).

Rawls, John (2005), Political Liberalism, Columbia UP, New York.

Rentsch, Thomas (1990), Die Konstitution der Moralität. Transzendentale Anthropologie und praktische Philosophie, Suhrkamp, Frankfurt/M.

Scheler, Max (1928), Die Stellung des Menschen im Kosmos, Bouvier, Bonn ( $\left.{ }^{1} 1928\right)$.

Shue, Henry (1996), Basic Rights, Princeton UP, Princeton.

Stehr, Nico, Henning, Christoph \& Weiler, Bernd (2009), The Moralization of the Markets, Transaction, Los Angeles.

Troeltsch, Ernst (2002), Naturrecht und Humanität in der Weltpolitik, in: Schriften zur Politik und Kulturphilosophie, KGA, vol. 15, De Gruyter, Berlin, 493-512 (11923).

Watzal, Ludwig (ed. 2004), Menschenrechte. Dokumente und Deklarationen, Bundeszentrale für politische Bildung, Froitzheim AG, Bonn.

Wetz, Franz Josef (2011), Texte zur Menschenwürde, Reclam, Stuttgart.

Wuerffel, Kristin (1998), Discriminating Among Rights? A Nation's Legislating a Hierarchy of Human Rights in the Context of International Human Rights Customary Law, in: Valparaiso University Law Review, 33/ $1,369-412$. 